\title{
Partisan Historiography?
}

\author{
T.P. Wiseman \\ University of Exeter \\ T.P.Wiseman@exeter.ac.uk
}

Received May 2020 | Accepted May 2020

Nandini Pandey's gratifyingly long and entertaining review of my book The House of Augustus is subtitled "Excavating Augustus and Partisan Historiography on the Palatine". ${ }^{1}$ Her nuanced account of the book's merits and shortcomings is summarised in the Abstract: "Sound archaeological arguments are couched within a less convincing attempt to reframe Augustus as a populist hero." The phrase in the subtitle, however, raises the stakes to a level beyond mere difference of opinion. What is it that makes a historical argument partisan?

Pandey refers to "the glowing portrait of Augustus as populist savior that emerges from and impels this book", and notes that "[i]n its swift pacing, palpable partisanship, and plot hole within a plot hole, Wiseman's 'detective story' rejects history sine ira et studio in favor of something more akin to the 2019 murder mystery Knives Out". ${ }^{2}$ A later formulation offers a bit more clarity:

Chapter 1, "Understanding Augustus", conducts an unabashedly proCaesarian recap of the last days of the Republic ... Though this introductory chapter upholds the importance of literary sources, it regularly dismisses optimates like Cicero as "biased" without acknowledging the other side's equal investment in their own version of events. ... The insistent moral binaries between senate and plebs, optimates and populares, are more polemical than persuasive. ${ }^{3}$

That last point has come up in another review of the book, by James Corke-Webster:

1 Pandey 2020, on Wiseman 2019.

2 Pandey 2020, 691.

3 Pandey 2020, 693. 
Wiseman's pejorative language makes this a story of heroes and villains. ... The polarization of contemporary political discourse into terminally opposed binaries has changed public life for the worse. It must be resisted, especially in the academy. ${ }^{4}$

Those are serious charges. What are they based on?

Careful reading of the relevant chapter reveals that the word 'biased' is never used, ${ }^{5}$ and the optimates' "investment in their own version of events" is in fact acknowledged. ${ }^{6}$ There is certainly some pejorative language, but it is the language of Sallust. ' 'Binaries', however deplorable, would be hard to avoid in an account of the polarised politics of the late republic; here the definition of them is taken from Cicero. ${ }^{8}$ The procedure is made clear at the start:

To understand Augustus, we need to understand the late republic. To understand the late republic, we need to take seriously what the ancient sources say about it. Those sources are uniquely authoritative and well informed, consisting as they do of the writings of contemporary participants whose understanding of the political culture of their time is, I think, beyond challenge. So the argument in this chapter will depend entirely on primary evidence, presenting a picture of Augustus' life and times through the words of contemporaries-including, of course, Augustus himself. ${ }^{9}$

The point is repeated at the start of the second chapter: "My aim throughout this book is to make the methodology as transparent as possible, by presenting the reader with the texts I think are important, and explaining as clearly as I can what I think they imply."

That should be uncontroversial, but Pandey objects to it, surprisingly on grounds of logic:

4 Corke-Webster 2020, 100.

5 The closest is Wiseman 2019, 11, where Antonius' statement in Cic. De or. 1.226 that 'the People has handed over to the Senate the power to guide and regulate it' is described as "a partisan view".

6 Wiseman 2019, 4: "for all optimates, it was self-evident that Caesar had been a 'tyrant', and his murder therefore both legitimate and heroic. But what criterion of 'tyranny' were they applying?"

7 Wiseman 2019, 3, 17 (Sal.Jug. 5.1, 42.1, Cat. 10.3-5).

8 Wiseman 2019, 1-2 (Cic. Sest. 96, Rep. 3.23).

9 Wiseman 2019, 1, picked up at 122 ("Throughout this enquiry we have tried to privilege eyewitness accounts, the evidence of people who were there at the time"). 
Wiseman announces a return to the sources themselves. However, rather than proceed inductively, building his case from an accumulation of evidentiary detail, Wiseman operates deductively, lending his argument an elegant circularity. ${ }^{10}$

The claim is a paradoxical one, since the book presents itself from the start as the "accumulation of evidentiary detail" from which the author draws his conclusions. ${ }^{11}$ Deductive reasoning is the application of a general rule, an axiomatic premise. Pandey explains:

This book takes Augustus at his word that he returned ownership of the res publica to the people, then uses this as an explanatory principle to interpret Rome's literary and material landscape. Since this landscape is characterized by absences and silences-including a lack of positive archaeological evidence for Augustus' home, and tacit constraints on literary speech ${ }^{12}$ - it can do little to resist. ${ }^{13}$

It may be argued that she herself is arguing deductively here, with the modern scholarly consensus of a repressive regime taken as the axiomatic premise from which those absences, silences and tacit constraints must be deduced. The question is, where does the burden of proof lie? Since we have first-hand contemporary evidence for Augustus' political aims and achievements, ${ }^{14}$ should the default position be to accept it (with whatever reservations), as I do, or to dismiss it as self-evidently untrue, as Pandey does on the strength of the current consensus?

I deliberately read forward to Augustus from the late-republican popularis tradition, emphasising the near-identical policy statements of Caesar in February $49 \mathrm{BC}$ and Augustus looking back six decades later. ${ }^{15}$ Both took for granted the necessity of freeing Rome from the grip of a dominant oligarchybut that very concept is controversial nowadays, and Pandey again sides with

\footnotetext{
$10 \quad$ Pandey 2020, 691.
}

11 Wiseman 2019, xvi: "[A]t every stage we shall be trying to make sense of obscure bits of evidence, looking for ways to turn inadequate information into a properly intelligible narrative. We have to go where the evidence leads, however unexpected the result may be."

12 See, e.g., Feeney 1992 and Pandey 2018, 24.

13 Pandey 2020, 691: the footnote is n. 2 in her text.

14 Wiseman 2019, 7, 10, 13, referring respectively to the Triumvirs' edict (quoted at App. $B C$ 4.8.31-32), Augustus' speech in 2 BC (quoted verbatim at Suet. Aug. 58.2), and his own account of what he did and why (Aug. Anc. 1.1-4).

15 Wiseman 2019, 2, 13 (Caes. Civ. 1.22.5, Aug. Anc. 1.1). 
the conventional wisdom: "The copious scholarship that offers reason to doubt Augustus' rosy self-portrait, or to differentiate between popularis and Caesarian politics, is buried in the back if mentioned at all."16 It is not clear how popularis and 'Caesarian' politics could ever be differentiated, since Caesar was notoriously 'the man who followed the popularis way in public life.' ${ }^{17}$ More important, however, is the fact that once again my position is based on the primary sources, Pandey's on the scholarly communis opinio.

We have been here before. A generation ago Fergus Millar was struck by "an extraordinary gap between the way the political life of the Republic seemed often to be portrayed and analyzed in the modern world and what appeared to present itself in the sources"; the result was the Jerome Lectures of 1993-1994, eventually published as The Crowd in Rome in the Late Republic. ${ }^{18}$ Millar's argument focussed closely on the primary evidence, ${ }^{19}$ and was attacked for that very reason:

He chose ... not to make the effort to embark on a detailed and differentiated exploration of the intricate channels (and somewhat roundabout ways) of approaching the problem of Roman politics and political personnel that international research has taken since the seminal publications of Friedrich Münzer and Matthias Gelzer in the first half of the last century; he just contented himself with a sweeping and one-sided look back in anger. ${ }^{20}$

In fact Millar's method was strictly empirical, "the collection, analysis and organisation of a body of evidence that is never explained a priori by a conceptual framework of interpretation". ${ }^{21}$

My method is the same, explicitly acknowledged. ${ }^{22}$ That was recognised by sympathetic reviewers of an earlier book, Remembering the Roman People,

16 Pandey 2020, 691. Cf. Corke-Webster 2020, 100: "This is based on a two-party view of optimates and populares that is the subject of heated academic discussion (of which Wiseman has been a vocal member), but that debate does not get much of a look-in here."

17 Cic. Catil. 4.9 (quoniam hanc is in re publica uiam quae popularis habetur secutus est); cf. Att. 7.3.5, 7.7.6, 8.3.4, 10.4.8 (popular enthusiasm for Caesar in 49 BC).

18 Millar 1998, viii.

19 Millar 1998, ix: "this book, by virtue of its nature as a slight essay [sic], does not engage seriously and directly with the great mass of modern literature on its topic."

$20 \quad$ Hölkeskamp 2010, 76.

21 Purcell 2017, ix (citing Benoist 2012, 11-12).

22 Wiseman 2017, 16-17. 
which was dedicated to Millar. ${ }^{23}$ Unsympathetic ones referred to "bold conjectures" and a "reluctance to define-or even explicitly discuss-his methodology". ${ }^{24}$ And now Pandey, referring to "Wiseman's imaginative talents", considers the popularis Augustus "a creative fiction". ${ }^{25}$ Just as Karl-Joachim Hölkeskamp accused Millar of a "one-sided look back in anger", so Pandey accuses me of "reject[ing] history sine ira et studio" and failing to "acknowledge the other side's equal investment in their own version of events". ${ }^{26}$

It would not be easy to find anger in either Millar's work or mine-but perhaps those who are committed to the consensus find it easier to attribute irrational motivation to their opponents than to engage with the evidence they present. That, surely, is what lies behind the notion of 'partisan historiography' Partisanship was inherent in the politics of the late republic, as Cicero explained to his audience in 56 вс. ${ }^{27}$ How it had come about, by the corruption of the Roman ruling class in the second half of the second century вС, was explained by Sallust. ${ }^{28}$ Both men knew how Roman politics worked incomparably better than any modern historian can, and the value of their evidence can hardly be exaggerated. But they were on opposite sides politically, and while Cicero is rightly given the credit he deserves, Sallust can still be dismissed as "virulently partisan". ${ }^{29}$

Why should that be? Sallust had retired from politics when he wrote his historical works, and his claim to be unprejudiced is amply borne out by the famous double character-sketch of Caesar and Cato in his Catiline. ${ }^{30} \mathrm{He}$ describes an ongoing conflict between the populus or plebes on the one hand and

23 Wiseman 2009: Classen 2010, 441 ("Durch sorgfältige Analysen aller denkbaren Quellen, in denen sich W. zugleich als stets zuverlässiger und scharfsinniger Philologe, Historiker und auch Archäologe erweist, läßt er immer neu die oft geleugnete oder vernachlässigte Rolle der römischen plebs wenigstens in den beiden letzten Jahrhunderten der römischen Republik klar und zuverlässig begründet erscheinen"); Beard 2013, 102 ("This book is ground-breaking for its simple suggestion that the ideology of popular politics is not entirely lost to us, and for its virtuoso demonstration that, fragmentary, inadequate and intensively studied as our sources for the period are, they may still have more to tell us").

24 Scheidel 2010, 337.

25 Pandey 2020, 690 (citing Beard 2013, 100 on "bold historical speculation").

26 Pandey 2020, 691, 693.

27 Cic. Sest. 96. Cf. Wiseman 2019, 169: "Modern historians' attempts to explain this passage away (e.g. Alston 2015, 353, Mouritsen 2017, 120-122) are a tacit admission that their preconceived ideas of what the republic was like are incompatible with the primary evidence."

28 Sal. Cat. 10-13, Jug. 41-42, Hist. 1.12-16 Ramsey.

29 Beard 2015, 265; cf. Cartledge 2016, 286 ("a client of Julius Caesar").

3 Sal. Cat. 4.2 (quod mihi a spe metu partibus rei publicae animus liber erat), 53.2-54.6. 
an arrogant aristocracy on the other. ${ }^{31}$ That does not fit with the view of the optimates that we get from most of Cicero, ${ }^{32}$ but it is perfectly compatible with what Caesar and Augustus both say they did - free the Roman people from the domination of an oligarchy. ${ }^{33}$ So who are the partisan historians here? Those who accept the view of 'late Cicero' without question, or those who also take account of what the opposition said?

All this affects only the first ten pages of The House of Augustus. Pandey is generously appreciative of the book's main argument on the topography and archaeology of the Augustan Palatine, complex and demanding though that argument is. But she is committed to the view that Augustus was an autocrat, "a ruler with the money, power, and influence to shape how people spoke of him". 34 "My own personal experiences," she writes, "have made me more skeptical than Wiseman about evidence that aligns too precisely with what people in power want us to think." 35 That is a statement that demands respect; but it does not entitle her to describe an empirical argument based on primary sources as 'partisan historiography'.

\section{Bibliography}

Alston, R. (2015). Rome's Revolution. Death of the Republic and Birth of the Empire. New York.

Beard, M. (2013). Confronting the Classics. Traditions, Adventures and Innovations. London.

Beard, M. (2015). SPQR. A History of Ancient Rome. London.

Benoist, S. (2012). Fergus Millar, un historien dans la cité. In: S. Benoist, ed., Rome, a City and its Empire in Perspective / Rome, une cité impériale en jeu, Leiden, pp. 1-17.

Cartledge, P. (2016). Democracy. A Life. Oxford.

Classen, C.J. (2010). Review of Wiseman 2009. HZ 290, pp. 439-442.

Corke-Webster, J. (2020). Roman History. G\&R 67, pp. 94-103.

Feeney, D. (1992). Si licet et fas est. Ovid's Fasti and the Problem of Free Speech under the Principate. In: A. Powell, ed., Roman Poetry and Propaganda in the Age of Augustus, Bristol, pp. 1-25.

Sal.Jug. 5.1, 27.2, 30.3, 31.2, 31.20, 40.3-5, 41.5-7, 42.1, Hist. 3.15.28 Ramsey. For the nobilitas as an oligarchy (pauci potentes, paucorum potentia) see also Cat. 20.7, 39.1, 58.11, Jug. 3.4, 31.19, Hist. 1.12, 3.15.6 Ramsey; also Hirt. Gall. 8.50.2 (contra factionem et potentiam paucorum). The Cicero of the Verrines (e.g. Ver. 5.175) is another matter.

33 Caes. Civ. 1.22.5, Aug. Anc. 1.1.

34 Pandey 2020, 692 ('My stake in the matter ...').

35 Pandey 2020, 700, drawing an analogy with Donald Trump. 
Hölkeskamp, K.-J. (2010). Reconstructing the Roman Republic. An Ancient Political Culture and Modern Research. Princeton.

Millar, F. (1998). The Crowd in Rome in the Late Republic. Ann Arbor.

Mouritsen, H. (2017). Politics in the Roman Republic. Cambridge.

Pandey, N. (2018). The Poetics of Power in Augustan Rome. Latin Poetic Responses to Early Imperial Iconography. Cambridge.

Pandey, N. (2020). Shovels Out. Excavating Augustus and Partisan Historiography on the Palatine. Mnemosyne 73, pp. 689-701.

Purcell, N., ed. (2017). Roman History. Six Studies for Fergus Millar (BICS 6o-1). London. Scheidel, W. (2010). Review of Wiseman 2009. AJPh 131, pp. 335-338.

Wiseman, T.P. (2009). Remembering the Roman People. Essays on Late-Republican Politics and Literature. Oxford.

Wiseman, T.P. (2017). Politics and the People: What Counts as Evidence? In: Purcell, ed., pp. 16-33.

Wiseman, T.P. (2019). The House of Augustus. A Historical Detective Story. Princeton. 